University of Michigan Law School

University of Michigan Law School Scholarship Repository

\title{
The Running with the Land of Agreements to Pay for a Portion of the Cost of Party Walls
}

\author{
Ralph W. Aigler \\ University of Michigan Law School
}

Available at: https://repository.law.umich.edu/articles/1151

Follow this and additional works at: https://repository.law.umich.edu/articles

Part of the Construction Law Commons, and the Property Law and Real Estate Commons

\section{Recommended Citation}

Aigler, Ralph W. "The Running with the Land of Agreements to Pay for a Portion of the Cost of Party Walls." Mich. L. Rev. 10 (1912): 187-211.

This Article is brought to you for free and open access by the Faculty Scholarship at University of Michigan Law School Scholarship Repository. It has been accepted for inclusion in Articles by an authorized administrator of University of Michigan Law School Scholarship Repository. For more information, please contact mlaw.repository@umich.edu. 
THE RUNNING WITH THE LAND OF AGREEMENTS TO PAY FOR A PORTION OF THE COST OF PARTY-WALLS.

WNERS of adjoining properties, especially in cities, frequently find it advisable and advantageous to enter into arrangements whereby their buildings shall be supported by a common wall. These arrangements are ordinarily evidenced by party-wall agreements or covenants, so-called, out of which have grown a number of interesting questions.

It not infrequently happeris that when one owner desires to build such a wall his neighbor, for one reason or another, is not ready to join in the undertaking, so an agreement is entered into between the two adjoining owners whereby one agrees to proceed with the erection of the wall at his own expense, the other granting the right to rest the wall one-half on his lot and agreeing to pay one-half the cost or value thereof when he makes use of it. The details of these agreements may vary almost without limit, but the main features are usually substantially as stated. Quite frequently the parties desire the benefits and burdens of the agreement to pass to and be binding upon future owners of the lots of the contracting parties, and the agreements are then entered into not only on behalf of the parties themselves, but their heirs and assigns are expressed as being bound, and frequently there is also a further clause that the agreements or covenants shall be construed as covenants running with the properties of the respective parties.

So long as the original contracting parties remain the owners of their respective lots, not much question can arise as to who is obligated to pay or who is entitled to receive such payment when the wall is made use of. It is when one or both of the lots are sold that very serious and troublesome questions arise along these lines, and there has been a lamentable lack of harmony in the decisions. Although many of the seemingly inconsistent conclusions may be explained on the basis of the wording of the contracts or the peculiar facts of the cases, there is clearly a diversity of view on the fundamental legal principles involved.

Let us take a typical case: $A$ and $B$ own adjoining lots. $A$ who is about to erect a building on his lot, desires to enter into an arrangement with $B$ whereby the wall supporting A's building on the side toward B's lot may be a party-wall and placed one-half on the lot of each. $\mathrm{B}$ is not then contemplating building presently, but 
is willing that A should build a wall of that nature, resting one-half of it on each lot, on the understanding that whenever he (B) should desire to build on his lot he may use the wall so built, and shall then pay $A$ one-half the cost or value thereof. Accordingly a contract is drawn up and executed by the parties, wherein and whereby it is provided in substance that A shall build a wall of a certain description, one-half upon the lot of each party, and that whenever $B$, his heirs or assigns, shall desire to use said wall they may do so, and shall then become liable to pay to A, his heirs or assigns, one-half the cost of said wall, or of so much thereof as shall be made use of. And it is further provided that the stipulations and agreements contained in said contract shall be construed as covenants running with the land of each party. Now if $B$ should use the wall while $A$ is still the owner of the adjoining lot, it is clear that $B$ would be liable to pay to $A$ one half the cost of the wall as provided by the contract. But suppose $B$ has sold his lot to $C$ and $C$ makes use of the wall to support a building on his lot, is $C$ liable to $A$ ? Or suppose $B$ keeps his lot and $A$ sells his to $D$ and after that sale $B$ uses the wall, is $B$ liable to pay $\mathrm{D}$ ? And to complicate the situation still more, suppose $B$ sells to $C$ and $A$ sells to $D$ and then $C$ makes use of the wall, is he liable to pay for a portion of the cost of the wall as provided by the original agreement between $A$ and $B$ ? And if so, to whom should he pay?

It is of course obvious that the answers to these questions depend primarily upon the general principles regarding covenants running with the land. It is therefore necessary that we consider the essential qualities of a covenant that may run with the land, with a view to determining whether party-wall covenants of the sort mentioned. may properly be classed among those that may run; after which, we shall consider very briefly the reported decisions in this class of cases.

The essential elements of a running covenant are, (I) a privity of estate between the covenanting parties ${ }^{1}$ and (2) the covenant must touch and concern the land with which it runs. ${ }^{2}$ To these may possibly be added a third-it must not appear that it was the intention of

${ }^{1}$ Cole v. Hughes. 54 N. Y. 444 ; Lyon v. Parker, 45 Me. 474; Wheeler v. Schad, 7 Nev. 204; Easter v. Railroad Co., 14 Oh. St. 48; Hurd v. Curtis, 19 Pick. 459; Hazlett v. Sinclair, 76 Ind. 488; Webb v. Russell, 3 Term Rep. 393; Keppell v. Bailey, 2 Myl. \& K. 5 I7.

2 Wheeler v. Schad, 7 Nev. 204 ; Gilmer v. Railway Co., 79 Ala. 569, 58 Am. Rep. 623; Wiggins Ferry Co. v. Railroad Co., 94 III. 83 ; Indiana Nat. Gas Co. v. Hinton, 159 Ind. 398, 64 N. E. 224; Savage v. Mason, 3 Cush. 500; Nat'l Bank v. Segur, 39 N. J. I. 17.3; Spencer's Case. 5 Co. 16 a; Congleton v. Pattison, 10 İast 130. (The cases that might properly be cited in this and the preceding note are almost without number). 
the parties that the covenant should not run. ${ }^{3}$ From the first resolution of Spencer's case $e^{4}$ there grew up a doctrine that when the covenant is with reference to a thing not in esse at the time the agreement is entered into, in addition to the elements above stated, "assigns" must be named in order to give to the covenant the running quality. There seems never to have been any good reason for this rule, and in many of the decisions.in the United States, especially in the later ones, the rule has been repudiated. ${ }^{5}$ In the States where this position has been taken the presence or absence of the word "assigns" in the covenant is important only as shedding light upon the intention of the parties as to whether the covenant should or should not run with the land so as to.bind the grantees thereof.

There are few things in the law so confusing as "privity of estate," the confusion being largely due, perhaps, to the fact that the expression is frequently used in entirely different senses. The strict rule of the early common law (with exceptions not necessary to consider here) was that the only persons who could sue or be sued for breach of a contract or covenant were those who were parties to the convention. Between the contracting parties there was privity of contract, and that was sufficient to support an action as between themselves. An assignee of the contract could not maintain an action thereon in his own name for breach of the contract, because there was no sort of privity between him and the parties to the agreement. Privity of contract is necessarily personal. At a very early time, just when is uncertain, theregrew up a doctrine, that actions for breaches of certain covenants could be brought by a person in his own name even though there was as between such person and the defendant no privity of contract, provided there was a privity of estate between them. Thus if A leased land to B and covenanted to keep the premises in repair, and thereafter $B$ assigned his term to $C, C$ could maintain an action against $A$ in case of breach of the covenant during the time $C$ was the holder of the term, and the privity was not-of contract but of estate. When $A$ leased to $B$ and made the covenant there was subsisting between them not only a privity of contract, because they had

A covenant which in its nature is personal cannot be made to run with land no matter how strongly is expressed an intention that it shall; but a covenant which might run may be kept from running by an expression of intention that it shall be personal. See Conduitt v. Ross, roz Ind. I66.

5 Co. 16 a.

- Sexauer v. Wilson, 136 Iowa 357, II3 N. W. 94I, I4 I. R. A. (N. S.) I85; Masury v. Southworth, 9 Oh. St. 341; Kelly v. Railroad Co., 23 Pa. Co. Ct. I77; Ecke v. Fetzer, 65 Wis. 55. 26 N. W. 266 : Gilmer v. Railway Co., 79 Ala. 569, 58 Am. Rep. 623; Flege v. Bridge Co., $28 \mathrm{Ky}$. I. Rep. 1257, 9I S. W. 738. In Fingland the doctrine was doubted in Minshull v. Oakes, 2 H. \& N. 793.

- Sexauer $\nabla$. Wilson, supra, and other cases cited in preceding note. 
contracted with each other, but there was also a privity of estate, and when B assigned his term the assignee stepped into B's shoes as to the estate, and the privity of estate which theretofore had existed as between $A$ and $B$ was shifted. So long as $C$ retained the term there was privity of estate as between $A$ and $C$, and when $A$ committed a breach of the covenant while $C$ was owner of the term $C$ was entitled to maintain an action in his own name against $A$ for such breach.

Just what is the particular thing that creates or amounts to privity of estate in such cases is perhaps not so clear. Between lessor and lessee, the covenanting parties, ( $I$ ) there passes an interest in land; (2) there is created as between them a relation closely analagous to the common law tenure, ${ }^{7}$ and (3) both parties own estates in the same subject matter. It might possibly be said that any one of these threc things creates or amounts to privity of estate as between the parties to the covenant. The early common law authorities did not take the trouble to define precisely what was the particular, precise thing that constituted the privity. As between the lessor and an assignee of the lessee the second and third possibilities are present, that is, there is between lessor and assignee of the term that same relation of so-called tenure, and they both have estates in the same subject matter. If the privity of estate is or is created by the mere passing of an interest in land between the covenanting parties, then the only ground for holding that there is, after the assignment, a privity of estate between lessor and assignee is the fact that the assignee has succeeded to the lessee's interest, and so has, quoad the estate, stepped into the place of the lessee. However, that in the case of leasehold estates there is a privity of estate seems never to have been much doubted, and after the STAT. 32 HEN. VIII. c. 34, covenants were allowed to run with the land and the reversion, irrespective of whether the covenant was a benefit or burden.

But in the case of conveyances of lands in fee simple, after the abolition of tenures as between foeffor and foeffee, the situation has not been quite so clear. Suppose A conveys lands to B in fee simple and covenants to keep in repair the buildings on the land conveyed, and $B$ conveys the lands to $C$, who sues $A$ for breach of said covenant while he, $\mathrm{C}$, was owner of the lands. Needless to say there is no privity of contract between $A$ and $C$. Is there privity of estate? The English courts and the courts in the United States have held

TIn Challis. Real Property (Ed. 3) 424 it is said that tenure is not properly applicable to relation of lessor and lessee. The author observes that the expression "leasehold tenure," though commonly used, is not accurate, for the reason that terms of years were mere contracts. 
uniformly that the benefit of a covenant may be attached to and run with land upon the conveyance of a fee simple estate between covenantor and covenantee. This doctrine may be explained upon one of two grounds : first, that the benefit of a covenant may be attached to landso as to run therewith regardless of privity of estate, or, second, that the mere conveyance of an interest in land and the succession to the rights of ownership therein is the medium creating the privity. ${ }^{8}$ In some jurisdictions the first ground is adopted, ${ }^{9}$ but undoubtedly the great weight of authority is to the effect that the covenant can be made to run only when there is a conveyance of land, or an interest therein, between the covenanting parties. ${ }^{10}$ The conveyance, then, in the case of fee estates must be the medium of the privity.

In England the burden of a covenant cannot be saddled upon land so as to bind subsequent owners thereof at law. ${ }^{11}$ This rule has been followed in a few of our States. However the great weight of authority in this country seems clear to the effect that burdens may be made to run as well as benefits. ${ }^{12}$ If a mere conveyance of land, or of an interest therein, between the covenanting parties is sufficient to create privity of estate in order to carry the benefit of a covenant, it would seem that the same thing would be sufficient to carry a burden. In the case of leasehold estates no distinction is made as to benefits and burdens; it is not held that one kind of conveyance or relation is required to carry a benefit, and that something different is required to carry a burden. So there seems no good reason why the same sort of privity that carries a benefit should not be sufficient to allow a burden to run in the case of fee estates.

In Morse v. Aldrich, ${ }^{13}$ it was held that a covenant could run with the land although, at the time of the making of the covenant, there was no conveyance of land, or of any interest therein, between the covenanting parties. In that case one Cook conveyed to Hull certain lands together with the right to take mud from a pond on the remaining lands of the grantor. The interest thus acquired by $\mathrm{Hull}$ in the remaining lands of the grantor was a profit a prendre. Hull

8 This confusion is largely due to differences in opinion as to the real situation in Packenham's case, Y. B.. 42 Edw. IIr. 3 pl. 14. See Sugden, V. \& P. (I4th Ed.) 58I, et seq., also Wald's Pollock on Contracts, p. 300 .

- Shaber v. St. Paul Water Power Co., 30 Minn. I79; Horn v. Miller, I36 Pa. 640 (semble).

20 Lyon v. Parker, 45 Me. 474; Hurd v. Curtis, 19 Pick. 459; Gilmer v. Railroad Co., supra; Hills v. Miller, 3 Paige 254; Nye v. Hoyle, I20 N. Y. I95; Mygatt v. Coe, 124 N. Y. 212, 26 N. E. 6II, II I. R. A. 646; Wheeler v. Schad, supra; Miller v. Noonan. I2 Mo. App. 370, 83 Mo. 343; Bull v. Beiseker, 16 N. D. 290, II3 N. W. 870, 14 L. R. A. (N S.) 514 .

11 Austerberry v. Oldham, $29 \mathrm{Ch}, \mathrm{D} .750$.

12 I Tiffany, Real Property, 752, and cases there cited.

2s 19 Pick. 449. 
conveyed the premises and the rights in the pond to the plaintiff, and after this conveyance the plaintiff and Cook entered into a covenant regarding the drawing off the water of the pond a certain number of times each year. Cook's lands then came to the defendant, who breached the covenant. In an action for such breach the main point considered by the court was whether the covenant bound the lands in the hands of the defendant, and the precise question was whether there was privity of estate. In the course of the court's opinion, WrLDE, J., said: "To create a covenant which will run with the land, it is necessary that thereshould be a privity of estate between the covenantor and covenantee. (Citing cases.) In these cases, and in most of the cases on the same subject, the covenants were between lessors and lessees; but the same privity exists between the grantor and grantee, where a grant is made of any subordinate interest in land; the reversion or residue of the estate being reserved by the grantor, all covenants in support of the grant, or in relation to the beneficial enjoyment of it, are real covenants and will bind the assignee."

And it is the doctrine of a number of courts that the benefit or burden of a covenant may be made to run with a parcel of land belonging to one of the covenanting parties although there has been no conveyance of that parcel, or of any interest therein, providing there has been a conveyance between them of the land to which the corresponding benefit or burden, as the case may be, is attached, or of some interest therein.14 Of course it is necessary in such cases, as it is in all others regarding running covenants, that the covenant should touch and concern the land to which it attaches.

On the matter of the sufficiency of a conveyance of a mere incorporeal interest in land, such as an easement or profit, to create the requisite privity of estate to carry a covenant, the authorities in this country and in England are not in accord. The American courts have uniformly held that the conveyance of such an interest is sufficient. ${ }^{15}$

Whether a particular covenant touches and concerns the land is almost as difficult a question as this matter of privity of estate, but in a different way. It is difficult because there is no way of determining absolutely, once for all, whether the covenant does as a matter of fact touch and concern the land. The determination of

14 Fitch v. Johnson, IO4 Ill. III; Scott v. Burton, 2 Ashm. (Pa.) 324; Crawford v. Witherbee, 77 Wis. 419; Bronson v. Coffin. 108 Mass. 175. II Am. Rep. 335; Hazlett v. Sinclair. 76 Ind. 488; Easter v. Railroad Co., 14 Oh. St. 48 . But see Brewer v. Marshall, 18 N. J. Eq 337, I9 N. J. Eq. 537; Waterbury v. Head, 12 N. Y. St. Rep. 36 ; Clark v. Devoe, I24 N. Y. 120; Dexter v. Beard, I30 N. Y. 549.

1s Sims, Covenants, p. I98, et. seq. 
the presence or absence of this quality is primarily and fundamentally a matter of judgment, and judgments differ, even among men equally intelligent and honest. That certain covenants do touch and concern the land all authorities agree, and, on the other hand, it is agreed with like unanimity that certain other covenants are inherently personal and collateral to land. Between these two extremes there is a wide range of covenants of different types, as to which there may well be differences of opinion. However, the decisions of courts extending over several hundred years have established certain tests and have laid down rules which courts should observe and follow in passing upon this question. While it is true that the determination of the problem as to whether a given covenant in a particular case does touch and concern the land is a matter of judgment, that judgment should be exercised in view of and with regard to decisions in analagous cases. Without such an attitude on the part of the courts uniformity and certainty in the law are indeed hopeless. ${ }^{16}$

A wide variety of covenants have been held to touch and concern. the land. It is the purpose here to refer only to a few which in their nature seem analagous to the usual party-wall covenant. Covenants

16 In Congleton v. Pattison, Io East 130, the question arose upon a covenant by a lessee of a mill to employ only such persons as were residents of a certain parish. The court held that the covenant did not touch and.concern the land. Lord Ellenborough, C. J.s said: "This is a covenant in which the assignee is specifically named; and though it were for a thing not in esse at the time, yet being specifically named, it would bind him if it affected the nature, quality, or value of the thing demised, inde. pendently of collateral circumstances; or if it affected the mode of enjoying it."

In Vernon v. Smith, 5 B. \& Ald. I, Best. J., said: "A covenant in a lease which the covenantee cannot, after his assignment, take advantage of, and which is beneficial to the assignee as such, will go with the estate assigned. ** The covenant here mentioned is not beneficial to the estate granted, in the strict sense of the words, because it has no effect until the estate is at an end, but it is beneficial to the owner, as owner, and to no other person. By the terms, collateral covenants, which do not pass to the assignee, are meant such as are beneficial to the lessor, without regard to his continuing the owner of the estate." And in Vyryan v. Arthur, I B. \& C. 4ro, the same learned judge said: "The general principle is, that if the performance of the covenant be beneficial to the seversion in respect of the lessor's demand, and to no other person, his assignee may sue upon it; but if it be beneficial to the lessor, without regard to his continuing owner of the estate, it is a mere collateral covenant, upon which the assignee cannot sue."

In Gilmer v. Railway Co., 79 Ala. 569, the court said: "It is impossible to lay down any fixed rule by which to distinguish in all cases real covenants, which run with the land. and are binding as such on heirs, devisees, and assignees, from those which aro merely personal, and are binding only on the covenantor and his personal representative. The subject is one full of intricate learning, and the decisions of the courts touching it are greatly conflicting, and far from satisfactory. * * It is observed by Mr. Washburn that such covenants, and such only run with the land, as concern the land itself, in whosoever hands it may be, and become united with and form a part of the consideration for which the land, or some interest in it, is parted with between tho covenantor and covenantee 2 Wash. Real Prop. (4th Ed.) 286 (16). And this is, perhaps, a correct-principle", 
to pay money rent are held, it seems without exception, to run with the land and the reversion. ${ }^{17}$ Covenants by lessors to purchase improvements which become part of the realty, ${ }^{18}$ and covenants giving the lessee, his assigns, etc., the option to purchase the fee at a fixed price or at a figure to be determined in a manner specified, have been held to run. ${ }^{19}$

Now what is the situation in the case of party-wall covenants of the sort indicated above, with reference to their having the qualities which seem to be necessary to a running covenant? Upon the execution of the sort of contract indicated it seems clear that an easement or profit ${ }^{20}$ is thereby granted by the non-builder to the builder, which easement or profit is the right to use such portion of the grantor's lot as may be covered by one-half of the wall. ${ }^{21}$ Whether there is created, at the same time, a cross-easement in the builder's lot in favor of the non-builder we shall have occasion to consider later. In either event it would seem, in view of the authorities above referred to, that there has been a sufficient conveyance of an interest in land to create privity of estate between the covenanting parties. There has been at least a conveyance of an interest in land from the non-builder to the builder, and after-such grant, there are in the covenanting parties mutual estates or interests in the same land, as was the case in Morse v. Aldrich. The decisions in the party-wall cases holding that the covenants do not run have generally been placed on grounds other than lack of privity of estate. Whether the covenants touch and concern the land or are merely personal requires a more

1T Stevenson v. Lambard, 2 Iast 575; Parker v. Webb, 3 Salk, 5 ; Williams v. Bosanquet, I Brod. \& B. 238; Midgley v. Lovelace, I2 Mod. 45 ; Salisbury v. Shirley. 66 Cal. 223. 5 Pac. x04; Allenspach v. Wagner, 9 Colo. x27, xo Pac. 802 ; Baldwin v. Walker, 2I Conn. 168; Webster v. Nichols 104 Ill. 160; Outtoun v. Dulin, 72 Md., 536; Pfaff v. Golden, 126 Mass. 402; Stewart v. Railway Co., 102 N. Y. 601; Fennell v. Guffey, $139 \mathrm{~Pa}$. 341, 20 Atl. 1048: State v. Martin, 82 'Tenn. (14 Lea) 92, 52 Am. Rep. I67.

$1 s$ Hunt v. Danforth, 2 Curt. (C. C.) 592 , Fed. Cas. No. 6887; Barley v. Richardson, 66 Cal. 416; Frederick v. Callahan. 40 Ia. 31I; Stockett v. Howard, 34 Md. I2I; Lametti v. Anderson, 6 Cow. 302; Bailie v. Redway, 27 Wis. I72; Ecke v. Fetzer, 65 Wis. 55, 26 N. W. 266; Hollywood v. First Parish. 192 Mass. 269, 78 N. E. 124. See also Thompson v. Rose, 8 Cow. 266 , where the court held that a covenant to purchase or pay for, improvements did not run, not because the covenant did not touch and concern the land, but because it was with reference to a thing not in esse and "assigns" had not been named.

Io Prout v. Roby 15 Wall 47 I (semble); Robinson v. Perry, 21 Ga. I83, 68 Am. Dec. 455; Page v. Hughes, 2 B. Mon. 439; Laughlin v. Perry. 35 Md. 352 ; Peters v. Stone. I93 Mass. 179, 79 N. E. 336; Van Horn v. Cram, I Paige (N. Y.) 455; Hagar v. Buck, $44 \mathrm{Vt}$. 285, 8 Am. Rep. 368; Re Adams and Kensington Vestry, $24 \mathrm{Ch} . \mathrm{D}$. 199, $27 \mathrm{Ch}$. D. 394. But see Woodall v. Clifton, (1905) 2 Ch. 257.

${ }^{20}$ In Littlefield v. Maxwell, $3 \times \mathrm{Me}$. ${ }^{3} 34$, it was held that if the right granted involved an exclusive use of the surface of the ground, a profit was created, and not a mere easement.

21 See party-wall cases hereinafter referred to. 
detailed consideration of the nature of the agreements and of the rights and relations created thereby.

There is a fundamental difference in the views of the courts as to the relation between the parties created by these party-wall agreements, which difference in view is the cause, it is believed, of at least a portion of the seeming conflict of authority on the subject. That difference is with reference to the ownership of the half of the wall placed on the non-builder's lot. It seems to be conceded that after the wall has been used and paid for according to the terms of the party-wall contract, there is a division of ownership, each one of the adjoining owners owning one-half of the wall, and with cross-easements of support. But the point of difference is as to whether there is such cross-easement in favor of the non-builder, and such severance of ownership of the wall, before such use and payment. It is believed that in construing these contracts with reference to whether or not they touch and concern the land, and whether the benefits and burdens created thereby run with the lots of the respective parties, it is a matter of material difference whether the half of the wall on the non-builder's lot and the cross-easement in his neighbor's wall and lot are-considered as belonging to him absolutely from the date of the contract, or whether the entire wall is deemed the property of the builder until such time as the non-builder shall make use thereof and, perhaps, make payment of his proportionate share of the cost. If the view be taken that each one of the lot owners owns his half of the wall together, of course, with crosseasements of support, then the real nature of the transaction would seem to be that the builder has furnished to the non-builder work, labor and materials in the building of the half of the wall on the latter's lot, and the obligation on the part of the non-builder is to pay for such work, labor and materials at such time as is specified in the covenant. Under this view, after the work, labor and materials are furnished, and the wall built, there exists between the parties to the contract merely the relation of debtor and creditor, and under such circumstances it is believed that the agreements, under the well settled rules regarding running covenants, cannot be made to pass with the lots of the parties into the hands of subsequent owners, for the reason that the contract is purely personal and collateral to the land.

On the other hand, it may be the view that the builder owns the entire wall with the right to have the same rest partly on his neighbor's lot, that the neighbor, the other covenanting party, acquires no cross-easement and no rights of ownership even in the half of the wall on his own land until he makes use of the wall, and that upon 
such use, and possibly not until payment is made therefor according to the terms of the covenant (depending upon the manner in which the covenant is drawn) there is granted to the then owner of the non-builder's lot a cross-easement of support and the ownership of so much of the wall as rests on his lot. If the builder owns the entire wall, it is a part of his lot, and upon a conveyance of such lot there would pass therewith the ownership of the wall. So if there is any such sale and transfer of a part of the wall and a grant of a crosseasement as suggested, it must be by the then owner of the builder's lot to the then owner of the lot adjacent, the terms of which sale and grant are determined by the provisions of the party-wall agreement. And if that is the real nature of the transaction, it seems clear that the covenant should be held to touch and concern the land, for it directly affects its use and occupation, and the authorities hereinbefore cited to the point that covenants to purchase improvements placed on demised premises or to sell premises in fee to the lessee thereof are closely in point. That there is such division of ownership and cross-easement created at the time of user and payment has been the view of the courts in a number of cases. ${ }^{22}$

But there are seeming difficulties in an acceptance of this view. Ordinarily there does not purport to be a grant of an easement or a transfer of a part of the wall at the time the wall is used; such grant and transfer, being of interests in land, can be made only with the formalities prescribed by law, such as a sealed or written instrument and a delivery thereof. Another possible objection is that there is a violation of the rule against perpetuities. If the covenant is construed as an option in the non-builder to purchase a part of the wall and the cross-easement, it would seem under the doctrine of London \&. S. W. Ry. Co. v. Gomm, ${ }^{23}$ and Woodall v. Clifton, ${ }^{24}$ that the rule against perpetuities is violated, for it may not be known, for a period of time longer than that allowed by the rule, in whom the estate will vest.

Oddly enough no court in a party-wall case has considered thise difficulties, which in itself is a potent, though by no means conclusive, argument against the soundness of the suggestions. The first point, regarding the creation and vesting of an interest in land, may perhaps be answered on the ground that the party-wall covenant itself is the instrument of transfer, it appearing that under modern law a conveyance may operate to pass an interest or estate in futuro. But this again brings us up against the rule against perpetuities.

\footnotetext{
2 See party-wall cases hereinafter referred to.

2320 Ch. D. 562.

24 (I905) 2 Ch. 257. See also Winsor v. Mills, 157 Mass 362.
} 
Perhaps the position might be taken in answer to the suggested violation of the rule that the interests in the wall and the crosseasement are created and vested in interest by the covenant, and that it is the enjoyment only which is postponed, thus avoiding both the matter of the conveyance and the violation of the rule. If this proposed view were tenable, it would seem clear that the covenant as to payment would touch and concern the land, it would look to the future, and should be held to run.

In the following pages will be found a brief consideration of the cases involving the phase of party-wall covenants indicated by the foregoing. It has seemed advisable and convenient to take up the cases classified according to States. Frequent reference will be made to the benefit of the covenant, and also to the burden. By the former is meant the right to receive payment according to the covenant, and by the latter is meant the obligation to make such payment. It should be noted, however, that as a matter of fact the covenant on each side is at the same time both a benefit and a burden.

Arabama. In Jebeles \& Colias Conf. Co. v. Brozm, ${ }^{25}$ an action was brought by the vendee of the builder against one who had succeeded to the rights and liabilities of the non-builder, though apparently not as the non-builder's vendee, to recover one-half the value of a partition wall. The contract under which the wall was built provided expressly that the "covenant shall run with the land and be binding on the present or future owners." It was held that the plaintiff should recover. This, then, was a square holding that the benefit runs with the land. The court was not called upon to decide whether the burden would run with the land of the nonbuilder, but that it would so run was clearly the opinion of the court.

ARRANSAS. In Rugg v. Lemley, ${ }^{28}$ the complainants, who were the successors in ownership of the builder's lot, brought an action in equity against the defendant, the owner of the adjoining lot, to recover one-half the cost of a party-wall built by the grantor of the complainants on the line between the two lots, it appearing that the defendant's lessee had made use of the wall. The widow of the builder of the wall intervened, claiming to be entitled to receive payment on the ground that the original contract between the lot owners was oral, that the wall therefore was the personal property of the builder, and that she had, under the will of her husband, become entitled to all his personal property. The report of the case does not show whether the party-wall contract was as a matter of fact oral. The court found for the complainants and dismissed the

25147 Ala. 593, 4I South. 626.

2078 Ark. 65, 93 S. W. 570, Ir5 Am. St. Rep. I7. 
intervenor's bill. In the course of the court's opinion, MCCuLLOCH, J., said:

"Under the contract, when the wall was built, the builder became the sole owner thereof, with an easement over the strip of the adjoining lot built upon, subject to the right of the owner of the adjoining lot to use the wall upon payment of half the cost thereof. The whole wall, together with the easement over the adjoining lot, passed under the deed executed by the builder as an appurtenance to his lot: $M c C h e s-$ ney v. Davis, 86 Ill. App. 380; Kimm v. Griffin, 67 Minn. 25, 69 N. W. 634, 64 Am. St. Rep. 385 .

"The owner of the adjoining lot, by paying half of the cost of the wall in accordance with the terms of the contract, not only obtained title to that part of the wall which was built upon his lot, but he also acquired an easement over the other lot for support of the wall. These consummated rights he obtained, not from the builder, the original owner of the lot, but through and from the person who was the owner of the lot at the time he used the wall and paid the agreed price. Though the rights of the parties were fixed by the original contract, yet the enjoyment of them was consummated only when the agreed price should be paid. [Italics ours.] Therefore, in contemplation of law, these rights were obtained through and from the present owner of the lot and wall, and he alone is entitled to the compensation."

If it was found as a fact that the original contract was oral, it is difficult to follow the court's argument. In Joy v. Boston Penny Savings Bank, ${ }^{27}$ where the party-wall contract was oral, it was held that the agreement could not run with the land. It may be that the fact in Rugg v. Lemley was otherwise than as alleged in the intervenor's bill.

Colorado. In Crater v. McCormick, ${ }^{28}$ it was held, under the facts before the court, that the right to receive payment was personal to the builder, but the contract was drawn in such manner that it was clearly apparent that the provisions regarding payment were intended to be personal.

District of Columbia. It was held in Eberly v. Behrend, ${ }^{29}$ that the owner of the non-builder's lot at the time use was made of the wall must pay one-half the value thereof to the then owner of the

27 II Mass. 60.

\$ 4 Colo. 196 .

${ }^{20} 20$ D. C. 215 . 
builder's lot. This decision, however, was controlled by -building regulations of the District.

GEORGIA. An oral agreement was entered into by $R$ and $B$, adjoining owners, whereby it was agreed that $B$ should build a partywall and that $R$ should pay for one-half of so much of the wall as he should use when he should build upon his lot. B built the wall and sold his lot to A. R; without having built on his lot, and therefore without having used the wall, also conveyed to $A$. B thereupon sued $R$ to recover one-half the cost of the wall. A testified that he paid $R$ more for his lot because of the presence of the wall. It was held that, inasmuch as no time was specified within which $R$ was to use the wall, he was to use it within a reasonable time, that having sold his lot without making use of the wall he had put it out of his power to do so, and that therefore $B$ was entitled to recover on the contract. $^{30}$ Perhaps not a great deal of weight should be attached to this holding on the question of the running of the agreements with the land, for a parol contract at common law was incapable of being attached to land so as to bind subsequent owners thereof, and it is a matter of considerable doubt whether at the present time it is possible to make a purely oral contract run with the land, except possibly in equity. ${ }^{31}$

ILliNors. Some of the cases in this State may seem, upon cursory examination, not in harmony with each other, but it is believed that a careful examination of the facts in these cases will show that they develop a doctrine consistent at least with themselves. In Roche v. Ullman, ${ }^{32}$, it appeared that the complainant and defendant's vendor, owners of adjoining lots, entered into a party-wall contract, the complainant to build the wall and the defendant's vendor to pay for same upon making use thereof. The contract provided expressly that the agreements and the terms thereof should be deemed binding on heirs and assigns, etc., and that the provisions thereof should run with the land. The defendant, having purchased the lot of the non-building owner, made use of the wall, whereupon a bill in equity was filed by complainant, the builder, against the defendant to recover compensation for use of the wall according to contract. It was held that complainant should recover. The court by Mr. Justice MULKEY, said (p. 19):

"But outside of the equitable views here suggested, we think the law is with appellee on other grounds. While the authorities are not altogether harmonious with respect to the

so Rawson'v. Bell, 46 Ga. $x 9$.

st See discussion and cases cited in Sims, Covenants, p. 188, et seq.

204 IIl. Ir. 
legal effect of covenants and agreements providing for the construction of party-walls between adjoining proprietors, yet we think the decided weight of authority establishes the proposition that an agreement under the hands and seals of such parties, containing covenants and stipulations like those found in the instrument we are considering, will, when duly delivered and acted upon, as was done in this case, create cross-easements in the respective owners of the adjacent lots with which the covenants in the agreement will run, so as to bind all persons succeeding to the estates to which such easements are appurtenant, etc."

This case was followed in Harris v. Dozier. ${ }^{33}$

In Gibson v. Holden, ${ }^{34}$ it was held that the right to compensation for use of the wall according to the contract was personal with the builder, and that the vendee of the builder could not claim such compensation. In this case, however, it appeared that it was the intention of the parties that immediately upon building the wall its ownership was severed. Therefore the right of the builder was a personal right, as for money advanced or property sold, which would not and could not pass to his vendees merely as such. This distinction was pointed out in Tomblin v. Fish ${ }^{35}$ and in $M c C h e s n e y$ v. $D a v i^{38}$ wherein the vendee of the builder was allowed to recover. The same distinction was made and Tomblin v. Fish referred to as a "well considered case" in Mickel v. York" in which it was held that the building owner, in the absence of a contrary intention appearing, owns the entire wall until the same is used by the adjoining owner, together with a permanent right of support upon the neighbor's lot. Mickel v. York on this point was followed in Beidler v. King. ${ }^{38}$

INDIANA. In Bloch v. Isham ${ }^{39}$ it was held that the plaintiff, the vendee of the builder's lot, could not recover one-half the cost of a party-wall which the contract provided should be paid by the nonbuilder, his heirs and assigns, the other party to the contract appearing to have used the wall after the plaintiff had purchased the land of the builder. The court in the course of its opinion said:

5072 III. App. 542.

3 II5 IIl. I99, 3 N. E. 282.

as 18 Ill. App. 439 .

5886 Ill. App. 380 .

${ }^{37} 175$ I1l. 62 .

sy 209 Ill. 302. See also holding to same effect, Glover v. Mersman, 4 Mo. App. 90;

Brown v. MrcKee, 57 N. Y. 684 ; Gorham v. Gross, 125 Mass. 232, 240.

28 Ind. 37 . 
"Schenck and Isham (the original owners) were not tenants in common of the party-wall, but each owned the part thereof on his side of the line. Schenck advanced the money to build Isham's moiety, on the agreement of the latter that he, or his heirs, would repay it when he or they should have occasion to use the wall. This is clearly a mere personal covenant, in nowise connected with, or affecting the enjoyment of, the lot conveyed to Bloch (the plaintiff)."

It is apparent from the above that the conclusion of the court in this case was based on the proposition that each one of the original owners, the contracting parties, owned one-half of the wall from the start and that there then arose between them the purely personal relation of debtor and creditor. The doctrine of this case, however, is materially modified by the later case of Conduitt v. Ross. ${ }^{40}$

In the last named case Ross and Hauck, who were adjoining owners, entered into a party-wall contract, Ross to build the wall and Hauck, his heirs, etc., to pay Ross for one-half the cost thereof when he (Hauck), his heirs, etc., used same. Ross conveyed his lot, but reserved the right to receive payment for the use of existing party-walls. Conduitt became the owner of the Hauck lot and used the wall which had been built by Ross, and thereupon this action was brought, on the contract between Ross and Hauck, by Ross against Conduitt on the ground that the contract to pay. for half of the cost of the party-wall ran with the land. The court held that the contract did run with the land so as to obligate Conduitt to pay for the wall according to the terms of the contract. The court said:

"By the contract under consideration, Mrs. Ross acquired. the right to enter upon the Hauck lot and erect and permanently maintain thereon a party-wall. This was a grant toher of an interest in land, and was of such a character that a perpetual covenant might be annexed to it. ***

"In consideration of this grant to her she covenanted to do an act beneficial to the remaining interest of Hauck; that act was the erection of a wall so situated as that one-half of it should rest on the margin of his lot, and the other half on hers, thus devoting each estate to the mutual support of the party-wall. She at the same time covenanted that when she should be reimbursed one-half of the cost of the wall, he, or his grantees, should acquire a reciprocal interest in her lot, and in legal effect become owners of one-half the party-wall.

4 roz Ind. 166. 
"This agreement created what has been aptly termed mutual or cross-easements in favor of each in the lot of the other, and was an arrangement mutually beneficial to both properties. Fitch v. Johnson, I04 Ill. III ; Roche v. Ullman, I04 IIl. II; Bronson v. Coffin, Io8 Mass. I75 (II Am. Rep. 335); Thompson v. Curtis, 28 Iowa 229."

On rehearing the court pointed out that it had been held in Bloch v. Isham, that the right to receive compensation for the use of the party-wall was personal to the builder, and that there was no intention on the part of the court to question the soundness of that conclusion.

It thus appears that in Indiana the burden runs with the nonbuilder's lot, at least if apt words are used to indicate that such is the intention, and that the right to receive compensation does not run with the land of the builder. In Conduitt v. Ross the question of who was entitled to receive the payment of one-half the cost of the party-wall was not involved, for Mrs. Ross at the time she sold her lot reserved the right to receive all such payments. As hereinbefore stated it is believed that if the court was of the view, as indicated in the above quoted extract from the court's opinion, that upon payment being made the non-builder, his heirs or assigns, then became owners of one-half the wall, it must necessarily follow that in the absence of an express reservation of the right to receive payment, as in the Conduitt case, such payment must be made to the owner of the builder's lot at the time the wall is used. On the other hand, if the relation of the parties created by the party-wall contract is of the nature pointed out in Bloch v. Isham, then it is believed that the payment must be made by and to the original contracting parties, on the ground that the contract is then purely personal in its nature, and not of such a character as that it may be annexed to land so as to bind subsequent owners thereof merely as such owners.

IowA. The subject is regulated by statute. $\S 2994$ et seq of CODE OF I897. It has been held that the right to receive compensation is with the owner of the builder's lot at the time the party-wall is used by the adjoining owner. ${ }^{41}$ And it would seem that the owner of the non-builder's lot at the time the wall is used is obligated to make the payment.

Kansas. In the rather recent case of Southworth v. Perring, ${ }^{42}$ the Supreme Court of Kansas was called upon for the first time to

\footnotetext{
2 Thompson v. Curtis. 28 Ia. 229. See also Zugenbuhler v. Gilliam, 3 Ia. 39r; Bertram v. Curtis. 31 Ia. 46 : Percival v. Ins. Co., $115 \mathrm{~N}$. W. $94 \mathrm{I}$.

2 7 I Kan. 755. 8I Pac. 48x, 82 Pac. 785, 2 I, R A (N. S.) 87.
} 
consider this troublesome question. The contract there sued upon provided expressly that "The parties hereto bind and obligate their heirs, executors, administrators and assigns to the fulfillment of all the terms and covenants of this agreement." The lots of both parties to the agreement had been sold before any use was made of the wall by the non-builder, so that the court was called upon to consider both whether the burden ran and whether the right to receive compensation passed to the grantee of the builder's lot. The court, after a careful examination of the authorities, concluded that both benefit and burden passed to the subsequent owners. In the course of the opinion the court said:

“*** the question whether the right to receive payment on account of the party-wall passes with successive grants of the land is a more difficult one than whether the obligation to make the payment devolves upon the person who joins to the party-wall. It is easier to find support in reason and authority for holding that the obligation to make payment runs with the land than for holding that the right to receive payment does."

Again :

"Without attempting to declare what general principles relating to the question presented are sustained by the greater number of decisions, we shall decide it upon these considerations: We regard contracts of the character of that here involved as in their nature so related to the real property affected, and so adapted to impose their obligations and bestow their benefits upon the successors in title of the landowners by whom they are made, that the purpose that they shall have that effect is readily to be inferred from the employment of language having any substantial tendency in that direction. In the present case we hold that the use of the clause making the terms of the contract binding upon the heirs, executors, administrators, and assigns of the parties sufficiently indicates that intention. What the effect of the omission of that provision might have been, we do not now determine."

KENTUCKY. In Ferguson v. Worrall ${ }^{43}$ it was held that the obligation to pay for the party-wall according to the provisions of the contract passed to successive owners of the non-builder's lot. The court clearly indicated that the benefit would also pass to the grantee

${ }^{43} 3$ Ky. L. Rep, 219, 101 S. W. 966, 9 I, R A (N. S.) I26I. 
of the builder. "The wall was designed to enhance and make more convenient the use of both the lots. Each of the adjacent owners had a defined, fixed interest in the wall. It was as firmly attached to and a part of each lot as any building erected on either of them could be. And the benefits and burdens attaching to the wall foilowed the ownership of the respective lots." The court thus indicates that although each one of the contracting parties owns his half of the wall the contract created rights and obligations which ran with the respective lots.

LoursianA. The Iowa statute above referred to was taken from the Louisiana Code. Cases from the latter State and in accord with the doctrine of the Iowa cases are Durel v. Boisblanc; ${ }^{44}$ Murrell v. Fowler ;5 Bruning v. N. O.C. \& B. Co. ;8 Lavillebeuvre v. Cosgrove. ${ }^{.7}$

MassachusetTs. In the leading case of Savage v. Mason ${ }^{48}$ the court held that covenants regarding the building, use, and payment for such use of party-walls, contained in a deed of partition, created rights and obligations which ran with the land into the hands of subsequent owners. The reason for so holding was stated by the court as follows:

“*** There was privity of estate between the covenanting parties in the land to which the covenant was annexed. the covenant is in terms between the parties and their respective heirs and assigns; it has direct and immediate reference to the land; it relates to the mode of occupying and enjoying the land; it is beneficial to the owner as owner, and to no other-person; it is in truth inherent in and attached to the land, and necessarily goes with the land into the hands of the heir or assignee."

In Maine v. Cumston ${ }^{40}$ the party-wall contract, it was held, did not create covenants running with the land for the reason that the contract was not signed and sealed by the defendant's grantor, one of the original contracting parties. It was held, however, that the defendant as grantee of the non-builder was liable to pay one-half the cost of the wall as upon an implied contract, on the theory that the entire wall until used by the adjoining owner, was the property of the builder or his grantees. This doctrine was followed in Stand-

14 L La. Ann. 407.

43 La. Ann. 366.

4I2 La. Am. 54r.

17 Ira. Ann. 324.

${ }_{3}$ Cush. 500.

48 Mass. 317 . 
ish v. Lawrence. ${ }^{\mathrm{so}}$ In.Richardson v. Tobey ${ }^{51}$ the court held that the owners at the time of the use were subject to the burdens and entitled to the benefits according to the doctrine of Savage.v. Mason, and that the result would be the same whether they followed the authority of that case or of Maine v. Cumston.

In King v. Wight ${ }^{52}$ it appeared that adjoining owners had entered. into a party-wall contract under seal whereby it was provided that either party might build a wall, the other to pay, upon using the wall, for one-half the cost of erecting the same. Both lots were sold after $\mathrm{a}$ wall had been built, and after the conveyances the wall was used by the non-builder's grantee. The contract expressly named "heirs and assigns." It was-held that the covenants ran with the land both as to burdens and as to benefits. The court indicated that immediately upon the erection of the wall it was owned one-half by each of the adjoining owners. But in Berry v. Godfrey, ${ }^{53}$ apparently the latest expression by the Massachusetts court upon this point, it is said:

"It is equally well settled by decisions in this State and elsewhere that, until it is appropriated by the adjacent owner under the contract, it is the property of him who built it, and. that, so far as it stands on the land of his neighbor, it is lawfully maintained there under a license which preserves to the builder all his rights of property in it."

It thus seems quite clear that the law in Massachusetts is to the effect that both benefits and burdens pass with the land, if there is privity of estate, if the contract is under seal signed by the parties, and if apt words are used to indicate that it is the intention that the covenants shall run. The doctrine stated is not shaken by the decision in Lincoln v. Burrage, ${ }^{54}$ sometimes referred to as standing for a different rule. Under the facts of that case there can be no doubt that the court correctly held that the covenant sued upon did not run with the land.

Michigan. Both benefits and burdens run with the land if such appears to be the intention. 55 The contract under consideration in the case cited.expressly bound the heirs and assigns of the parties, and provided that the agreements of the parties should be construed as covenants running with the land; there was also a clause that

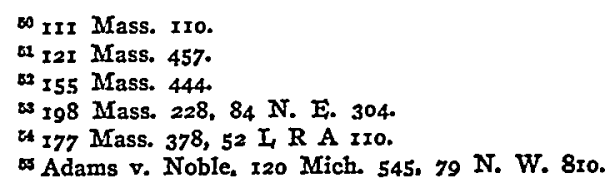


when the non-builder should pay one-half the cost of the wall he should then have a joint interest therein. In concluding that the covenants ran with the land the court laid stress upon this latter clause.

MINNESOTA. In Kimm v. Griffin ${ }^{50}$ the court held that the benefits and burdens both ran with the land. This case was followed in National Life Ins. Co. v. Lee, ${ }^{57}$ in which case the court said:

"*** By the terms of the party-wall contract, the payment of one-half the value-not the cost- - of the part of the wall proposed to be used was expressly made a condition precedent to its use. The only fair and rational construction of the contract is that the whole wall was to remain the property of Glessner (the builder), his heirs or assigns, subject to the right of Day (the non-builder), his heirs or assigns, to purchase so much of it as he or they might desire to use by paying one-half of its value, when-and not till then-he or they would acquire title to one-half of the wall.

"This wall was appurtenant to lot 8 , and as such all the right, title or interest of Glessner in it passed to plaintiff, under the title to that lot acquired under, etc."

In this case the contract under consideration provided that the agreements should be perpetual and run with the land.

Mississippi. Apparently the only decision involving the phase of party-wall law under discussion is that in Mayer v. Martin. ${ }^{\text {ss }}$ There, however, the contract considered was a mere parol agreement, and the court held that the provisions thereof did noi ex:end to subsequent owners. The court observed that if the agreement did run, payment would have to be made to the owner of the lot with the wall at the time the wall was used and not to the subsequent vendee of such then owner.

Missourr. In Huling v. Chester ${ }^{59}$ it was assumed for the purposes of the case that the obligation to make payment passed with the land of the non-builder. On the ground that the right to compensation was personal to the builder, the plaintiff, who sued as heir of the builder, was not, however, allowed to recover. Whether the failure to name "heirs and assigns" of the builder had any influence upon the court's conclusion does not appear. In a case decided the same year the supreme court held that party-wall contracts of the nature under consideration could not run with the land at law be-

\footnotetext{
56 67 Minn. 25. 69 N. W. 634 .

${ }^{77} 75$ Minn. 157. 77 N. W. 794.

*s 83 Miss. 322, 35 South. 218.

59 I9 Mo. App. $60 \%$.
} 
cause there was no privity of estate; but the action was in equity, and the court held that. the grantee of the non-builder was liable on the contract for the reason that he took with notice thereof. ${ }^{30}$

NEBRASKA. In a number of cases it was held that the obligation to pay passed to and bound subsequent owners. ${ }^{61}$ In Cook v. Paul ${ }^{62}$ it was held that the grantee of the builder was not entitled to receive payment under the party-wall contract as against the assignee of the builder. Whether or not the burden of making payments passed to the grantee of the non-builder was not involved, but the broad rule was laid down that in neither aspect could the agreements run. But in Loyal Mystic Legion v. Jones ${ }^{63}$ the court refused to recognize the doctrine of Cook $\nabla$. Paul as authorative or binding, and held that under the facts there presented both benefit and burden ran with the land. It should be noted that the contract provided that payment should be made to the builders "or their grantees," which fact the court was of opinion distinguished the case before them from those cases in which it appeared that payment was to be made to the builder or his assigns.

NEW YORK. Perhaps the decisions in no State have had so much influence upon the development of the law on this subject as those' of New York. In some of the early cases it was held that the covenants ran with the land. ${ }^{84}$ But in 1873 in the leading case of Cole v. Hughes ${ }^{\circ 5}$ it was held that neither burden nor benefit ran with the land. Judge EARL, who wrote the opinion of the court, was of opinion that the right to receive payment was personal to the builder, and that, inasmuch as no interest in the non-builder's land had been granted, there was no privity of estate and that therefore the burden of payment could not run. Because of the wide influence of this case the following extract from the opinion of Judge EARL is given:

" *** When Dean (the builder) conveyed he conveyed all his interest in the lot, and, as appurtenant thereto, in the party-wall. For this interest the grantee paid, and he got all he paid for. There can be no reason in equity why he should also receive payment for some portion of the cost of building the party-wall. *** The money to be paid was not for anything done upon the Dean lot, but for something

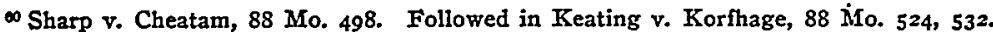

o Burr v. Lamaster, 30 Neb. 688; Stehr v. Raben, 33 Neb. 437; Jordan v. Kraft, 33 Neb. 844; Garmire v. Willy, 36 Neb. 340 .

${ }^{62} 4$ Neb. (Unof.) 93, 93 N. W. 430,66 I. R. A. 673.

$73 \mathrm{Neb}, 342,102 \mathrm{~N}$. W. $62 \mathrm{r}$.

U Weyman v. Ringold, I Bradf. 40 ; Keteltas v. Penfold, 4 E. D. Smith I22.

65 54 N. X. 444 . 
done upon the Vorhees (the non-builder's) lot, and it no more passed to his grantee than it would if he had built a house upon the Vorhees lot, using the party-wall, and Vorhees had agreed to pay him whenever he or his heirs or assigns should use or occupy it."

Again on page 447:

"The rext important question to be considered is, whether the agreement of V.orhees to compensate Dean ran with the Vorhees lot, so as to bind his subsequent grantees. I do not think it did. At the time Vorhees made the covenant he received no interest in land and granted none. He simply assented that Dean might build one-half of the wall upon his land, and then he agreed in a certain contingency, which might or mightnot happen, that he would compensate him. He did not convey to Dean any land upon which the wall was built. They continued to own the land, as before, in severalty, and, except for the agreement, Vorhees could have used the party-wall at any time without making compensation. (Sherred v. Cisco, 4 Sand. Sup. C. R. 480; Partridge v. Gilbert, I5 N. Y. 6or ; 2 WASHBURN, REAL PROPERTY, 334.)

'Dean's right to compensation was in no way charged upon the Vorhees lot. There was, therefore, no privity of estate. between Vorhees and Dean."

Cole v. Hughes was followed in Scott v. McMillan ${ }^{68}$ and in Hart v. Lyon. . ${ }^{\circ 7}$

In Mott v. Oppenheimer ${ }^{68}$ it was held that both the right to receive compensation and the obligation to pay passed to the successive owners of the lots of the contracting parties. The seeming conflict in the holding in this case with the rule of Cole v. Hughes and the cases following it was explained in Sebald v. Mulholland ${ }^{\circ}$ on the ground that in the Cole case it was contemplated by the parties and provided by the contract that one of the parties was to build and the other to pay for the wall, while in the Mott case the contract provided that either one of the parties might build and that the other should pay. The form of the contract in the Cole case, it was held, indicated that the rights and obligations were purely personal, and that merely privity of contract was created thereby, while in the Mott case the contract looked to the future and a privity of

$\infty 96$ N. Y. $14 \mathrm{I}$

90 N. Y. 663 .

${ }^{2} 135$ N. Y. 32.

I55 N. Y. 455 . 
estate was created. In the late case of Craveford v. Krollpfeiffer ${ }^{70}$ the court approved the doctrines of the Cole and Mott cases and affirmed the distinction pointed out in Sebald v. Mulholland. Thus it seems that if the parties will be careful to omit any specification of the party that is to build the wall and will draw their contract along the lines of the contract considered in Mott v. Oppenheimer, there will be no difficulty in passing the rights and obligations on to the subsequent owners. ${ }^{71}$

OHro. In Platt v .Eggleston ${ }^{72}$ the court was called upon to decide whether the payment for one-half the cost of a party'wall should be made to the builder of the wall or to his grantees. The court considered the entire-wall, together with the easement of support upon the adjoining lot, as appurtenant to the lot of the builder, liable, - however, to be subjected, under the agreement, to a burden for the benefit of the adjoining premises. "But when," said the court, "the property was subjected to such use by the adjoining owners, it was to be paid for. The right was not exercised until Wilson and Eggleston became owners of the property; and, it seems to us, as their property was required to bear the burden, they ought to receive the compensating benefit, and that this may fairly be presumed to have been in accordance with the intention of the parties to the original agreement." That the burden also should run was the conclusion of the court in Mithoff v. Hughes. ${ }^{73}$ And in. Hall v. Geyert the court said that a party-wall contract was one having "reference to land, and concerning title and rights in land, and of such nature and import as readily indicates its character and fixes its place in the classification of contracts, as one of those which, in legal parlance and in consonance with the great weight of the decisions on the subject, are denominated 'contracts or covenants running with the land."

Pennsylvania. By an act passed in I72I it was provided that "the first builder shall be reimbursed one moiety of the charge of such party-wall, or for so much thereof as the next builder shall have occasion to make use of, etc." Under this act the courts necessarily had to hold the right to compensation a chose in action personal to the first builder. ${ }^{75}$ In Hart v. Kucher $^{76}$ it was pointed out

T0 195 N. Y. 185 .

7 Some of the later cases in the lower New York Courts are Duer v. Fox, 60 N. Y. Supp. 580 ; Frick v. Bauer, 81 N. Y. Supp. 625 ; Schwenker v. Picken, 86 N. Y. Supp. 68x; Morris v. Burr, I12 N. Y. Supp. 243.

720 Oh. St. 414 .

75 O. C. C. 120 .

714 O. C. C. 229.

75 Todd v. Stokes, to Barr. 155 ; Gilbert v. Drew id. 219.

" 5 S. \& R. I. 
that this chose in action idea was based on the act of I72I. By an act passed in 1849 the law was changed so that the right to receive compensation passed to the first builder's grantees. Of this later act the court said:

"This is making the interest to be in law what it always was in fact, an interest in the realty, and not a mere personal right."'77

TExas. In Nalli v. Paggi, ${ }^{78}$ an oral agreement to pay a portion of the cost of erecting a party-wall, entered into when the wall was . partially built, was held not to run with the land, so as to bind a subsequent owner of the adjoining lot. The court cited and quoted from Cole v. Hughes on the point that there was no privity of estate and no interest in the land created by the agreement.

WashingtoN. Hoffman v. Dickson ${ }^{70}$ held that the party-wall contract involved in the case created an incumbrance on the lot of the non-builder, and that the incumbrance could not be discharged until the wall was used, for not until then could it be known to whom payment should be made. And in Sandberg v. Rowland ${ }^{80}$ it was held that the burden and the benefit both ran, it appearing that such was the intention of the parties. These cases were considered as binding authority in the very recent case of Hawkes v. Hoffman..$^{82}$

WEST VIRGINIA. A party-wall contract which expressly named "heirs and assigns" and provided in terms that it should run with the land was held in Parsons v. Baltimore B. \& L. Assoc. ${ }^{82}$ not to have created agreements running with the land either as to benefits or as to burdens, beyond an equitable charge imposed upon the nonbuilder's lot from the start. In support of the proposition that the agreements did not run with the land so as to bind subsequent owners personally, the court relied upon the authority of the New York cases referred to above.

ONTARIO. In Kenny v. Mackenzie $e^{83}$ the court held that the right to receive compensation did not pass to the grantee of the builder. The conclusion of the court was based on the ground that the agreement in the respect under consideration did not touch or concern the land.

ENGLAND. The general question seems to have been considered

77 Knight v. Beenken, 30 Pa. 372. See also Voight v. Wallace, 179 Pa. St. 520.

73 81 Tex. 20x, 16 S. W. 932, I I. R. A. 33.

To 47 Wash. 43I; 92 Pac. 272, 93 Pac. 523, 125 Am. St. Rep. 907.

- ${ }^{50} 5 \mathrm{I}$ Wash. 7, 97 Pac. 1087.

${ }^{2} 56$ Wash. 120, 105 Pac. 156, 24 L. R. A. (N. S.) 1038.

84 W. Va 335, 29 S. E. 999, 67 Am. St. Rep. 769.

$\$ 12$ Ont. App. Rep. 346. 
for the first and only time in a reported case in Irving v. Turnbull. . $^{4}$ It was there held that when an estate had been laid out in plots for building upon the condition (inter alia) that the purchaser of a plot first building a party-wall is to be repaid by the purchaser of the adjoining plot one-half of the value of the party-wall, and the original purchasers of plots sell their plots, either built upon or vacant, to other purchasers; an implied contract arises between these sub-purchasers of adjoining plots, that, as between them, the subpurchaser of a vacant plot, adjoinging a plot on which a house has already been built by an original purchaser, when he builds his house up to the house already built and makes use of its gable walls, shall pay to the then owner of the house, and not to the original builder, the half cost of the party gable wall. Thus the relations of the parties were there worked out on the basis of an implied contract, and not on the basis of covenants running with the land. The court took especial pains to point out that the payment should be made to the then owner of the builder's lot and not to the original builder himself, and principally on the fact that the entire wall belonged to the builder and the successive owners of his lot.

It appears, then, that in by far the greater number of States it is held that the covenants may properly be classed as running covenants. In a few it has been held that while the obligation to pay will run, the benefit, or the right to receive payment, is personal. This distinction, unless founded upon the wording of the agreement, is, it is believed, unsound. And in three or four States it is held that neither benefit nor burden may run with the land, unless perhaps, as in New York, the covenant is drawn along the lines laid down in Mott v. Oppenheimer. ${ }^{85}$ However it is unfortunate that the courts in many of the cases have not placed their decisions on grounds more satisfactory and unassailable.

UNIVERSITY OF MICHIGAN.

RaIPH W. Aigler.

69 L. J. Q. B. (N. S.) 593.

$\triangle 135$ N. Y. 312 . 